\title{
DIGITAL MEDIA LITERACY, SCHOOL AND CONTEMPORARY PARENTING
}

\section{Lana Ciboci :: Danijel Labaš}

ORIGINAL SCIENTIFIC PAPER / DOI: 10.20901/ms.10.19.5 / SUBMITTED: 22.04.2019.

ABSTRACT Today's societies live in a world where the media construct reality, which also affects each individual media user. Children and their parents spend most of their time with digital media and contents. Therefore, researchers emphasize the importance of digital literacy of media users. They analyse new phenomena, challenges and risks associated with the anthropological, cognitive and social development of children and young people. An important role in media and digital education is played not only by teachers and schools, but also by parents and family. The aim of this paper is to present and analyse the theoretical approaches to digital media literacy, so-called digital parenting, and to interpret the results of the latest research in Croatia devoted to the digital habits of parents, their attitudes towards parental mediation strategies as well as to their satisfaction with the programmes of media literacy in the education system.

KEYWORDS

MEDIA LITERACY, DIGITAL LITERACY, CHILDREN, PARENTS, MEDIATION STRATEGIES

Authors note

Lana Ciboci :: Edward Bernays University College, Zagreb, Croatia :: Iciboci@gmail.com

Danijel Labaš :: University of Zagreb, University Department of Croatian Studies, Zagreb, Croatia :: dlabas@hrstud.hr 


\section{INTRODUCTION}

The fact is that today's children "live mediatized childhoods and it is no longer possible to contemplate children's social and cultural worlds without considering the role played by the media" (Pereira, 2013: 172), especially by new digital media (Elea and Miklos, 2017). In fact, the media have an enormous impact on societies and people's lives. Therefore, there is a huge concern about the impact of digital technologies not only on children's lives, but also on the everyday lives of families as Sara Pereira stated when questioning if the introduction of more technology can really lead to better childhoods or even to better human relations.

Mascheroni and Pasquali (2013) state that "Digital media have become a pervasive component of children's lives in contemporary Western societies: children grow up in a convergent media ecology (Ito, 2009, according to Mascheroni and Pasquali, 2013: 84), whereby a variety of everyday practices - self-expression, sociability, learning, games, cultural consumption, etc. (Turkle, 2011: 259) - take place"- Furthermore, the authors claim that, in contrary to what is argued by media panics inspired positions (which emphasize the fear that online, mediated relationships are replacing offine, 'authentic' interactions), "children are integrating the online and the offine" (Livingstone, 2009: 31, according to Mascheroni and Pasquali, 2013: 84) in seeking to develop a coherent projection of the self. In other words, Giovanna Mascheroni and Francesca Pasquali, together with Sonia Livingstone, call for a contextualization of media practices within children's own worlds, keeping in mind that contemporary childhood is increasingly mediated, and the media environments are both changing in late modernity (Livingstone, 2009, according to Mascheroni and Pasquali, 2013: 84) and co-determining each other.

Therefore, "positive and negative aspects of media in children's lives cannot be studied without adding the complexity of everyday life. Children have the ability to communicate across cultural borders and they have access to participate in borderless media cultures. Depending on the content and what sense it makes to children we can discuss benefits or losses for the individual user" (Sundin, 2013: 18), and make an analysis of the complex research area of children media use and parents' relation to it.

On the other hand, the new digital environment raises new questions because "the information era has brought about new literacies" (Torres and Mercado, 2006: 260), and one of the most important literacies in the $21^{\text {st }}$ century in our digital societies is critical digital media literacy, which includes not only the possibility of having access to the media, but also - even to a significantly greater extent - the capacity to analyse, to evaluate and to create media contents (Aufderheide, 2013; Buckingham, 2005; Livingstone, 2003; Masterman, 1985, according to Tilleul et al., 2015: 76). Divina Frau-Meigs writes: "Since the advent of Web 2.0, Media and Information Literacy (MIL) is facing a new mutation, as interactivity and the Internet of things create a sense of augmentation of online activities, and as the industrial lobbies pressure governments in favour of computer literacy. This pressure is not problematic per se, but implies the digital affordances as they affect information under its various definitions (code, data, document, news)" (Frau-Meigs, 2015: 13). 
However, what have these changes and developments in the digital media world brought to the audiences - to children, youth, adults, teachers and parents? Several diverse studies (Lemish and Götz, 2017; Blades et al., 2014; Kirsh, 2006) have presented various open questions, problems, risks and even dangers, such as manipulation, violence, fake news, disinformation, propaganda, loss of interpersonal relationships, sensationalism, stereotypes etc.

For this reason, in this paper we will present and analyze the results of the first national research project on children's digital habits and attitudes of parents on media literacy in Croatia.

\section{NEW EDUCATIONAL CHALLENGES: FROM LONELINESS AND INTERNET ADDICTION TO DIGITAL DEMENTIA}

There is a great discrepancy in the development, but also the recognized importance of media education among European countries. While in some countries the importance of media literacy has been fully recognized by the state that included it in the education system a long time ago, in other countries media education has just begun to develop (Ciboci, 2018). In Croatia, on the issue of the development of media education policy, little has been done since the attainment of state independence in 1991 (Kanižaj and Car, 2015: 23). As Nada Zgrabljić Rotar (2005) points out, civic associations in Croatia are paying more attention to media literacy, which "should be included in all levels of the Croatian education system in the modern concept" due to the fact that within the framework of the curriculum at that time media literacy was present "only as much as it is interesting for teachers within the Croatian language in elementary schools, without appropriate literature and methodology" (Erjavec and Zgrabljić, 2000, according to Zgrabljić Rotar, 2005: 37 ). Karmen Erjavec also writes that at that time media education "in the Croatian school system was still at the beginning", and that it was mostly limited to film education (Erjavec, 2005: 98). Today's state of media education in Croatia has not changed much. The biggest changes are foreseen by the curricular reform that is currently under way in Croatia, which will be described in more detail below. For instance, more emphasis is put on the changes in communication that were primarily brought about by the usage of digital media.

The author of Second Self (1984) and Life on the Screen (1995) Sherry Turkle, in her book Alone Together (2011), has raised more questions about our interpersonal relationships in communication by asking how computers are changing us as people (Turkle, 2011: X) and why we expect more from technology and less from each other. She does not agree that computers and new digital devices, such as smartphones, iPods, iPads and tablets, are "just tools", adding that people are shaped by the tools they use. The focus of her research on networking was on the young. However, she also spoke with adults who gave her "insight into how the network is changing parenting and communications patterns" (Turkle, 2011: $\mathrm{XIII}$ ). She underlines that the technology is seductive and that digital connections and "the sociable robot may offer the illusion of companionship without the demands of 
friendship. Our networked life allows us to hide from each other, even as we are tethered to each other. We'd rather text than talk" (Turkle, 2011: 1). In the case of children, she is concerned about their getting comfortable with the idea that a robot's companionship is even close to a replacement for a person, and because teenagers believe that "texting is always better than talking", some of them "comment that it would be good to learn how to have a conversation 'sometime, but not now'" (Turkle, 2011: 65). According to her, the Japanese "take as a given that cell phones, texting, instant messaging, email, and online gaming have created social isolation. They see people turning away from family to focus attention on their screens. People do not meet face to face; they do not join organizations. In Japan, robots are presented as facilitators of human contact that the network has taken away", but there is an open problem: "Robots, which enchant us into increasingly intense relationships with the inanimate, are here proposed as a cure for our too intense immersion in digital connectivity" (Turkle, 2011: 146-147). Therefore, people love their new technologies of connection because "they have made parents and children feel more secure and have revolutionized business, education, scholarship, and medicine", they have changed how we date and how we travel, and "beyond all of this, connectivity offers new possibilities for experimenting with identity and, particularly in adolescence, the sense of a free space, which Erik Erikson called the moratorium. (...) Turkle (2011: 152) claims that "real life does not always provide this kind of space, but the Internet does", and warns that "virtual places offer connection with uncertain claims to commitment" (Turkle, 2011: 153). Moreover, the author adds that anxiety is part of the new connectivity (Turkle, 2011: 242). Indeed, more and more people live in what has been called "postfamilial families": "Their members are alone together, each in their own rooms, each on a networked computer or mobile device. We go online because we are busy but end up spending more time with technology and less with each other. We defend connectivity as a way to be close, even as we effectively hide from each other" (Turkle, 2011: 280-281).

Furthermore, teenagers complain that parents do not take their eyes off their phones at dinner and that they bring their phones to school sporting events. "Parents say they are ashamed of such behaviour but quickly get around to explaining, if not justifying, it", adding that they are more stressed than ever and they complain that their employers require them to be constantly online. Finally, parents admit that "their devotion to their communications devices exceeds all professional expectations" (Turkle, 2011: 164), which means that they have some signs of (new) media or Internet addiction (Carlisle et al., 2016; Weinstein et al., 2014) .

In accordance with Turkle's view, Laura Perdew asserts that, "in today's digital world, there seems to be a thin line between technology use and abuse. Many people's Internet habits may seem excessive: sleeping with a smartphone under the pillow, texting one person while having a face-to-face conversation with another, or tweeting from a funeral. But some people cross that thin line even one step further, going from Internet use and abuse to Internet addiction" (Perdew, 2014: 25; Young and Nabuco de Abreu, 2011). In addition to the aforementioned problems with addiction, the problem of obesity, insomnia, hyperactivity or memory problems are often associated with children's use of the media. To these effects, one must add effects of phone addiction by children and 
young people who are neglecting face-to-face communication and conversations (Turkle, according Perdew, 2014: 52-56), and the loss of privacy by "sharing too much" on social networks and in "virtual life" (Perdew, 2014: 57-65).

German neuroscientist Manfred Spitzer coined a new term regarding users of new digital technology: "digital dementia" (Spitzer, 2018), with which he describes an overuse of digital technology resulting in the breakdown of cognitive abilities. Writing on digital dementia, Spitzer starts with studies conducted by Korean researchers who recorded "a significant increase in the number of disorders of memory, attention and concentration as well as emotional and general perception by young people. They described this clinical picture as digital dementia" (Spitzer, 2018: 8).

Another problem raised by Spitzer is multitasking activity performed by children and youth today connected with attention and concentration disorder (Spitzer, 2018: 212224). As Turkle writes, years ago, there were some "idealizations when it became clear that networked computers facilitated human multitasking. Educators were quick to extol the virtues of doing many things at once: it was how the future wanted us to think. Now we know that multitasking degrades performance on everything we try to accomplish. We will surely continue to multitask, deciding to trade optimum performance for the economies of doing many things at once. But online multitasking, like online reading, can be a useful choice without inspiring a heroic narrative" (Turkle, 2011: 242).

In our modern context, it is a fact that new media and new digital technologies are a challenge in education topics, because new technology can lead to new open questions, challenges, risks and even addiction (Perdew, 2014: 25; Lin and Lei, 2015; Li et al., 2015). On the one hand, at the anthropological level, it can be seen that the new media can harm human relationships and direct interpersonal communication, as Turkle and Spitzer write (Turkle, 2011; Spitzer, 2018. On the other hand, the fact is that children and young people, being socialized by the media (Spitzer, 2018: 104-123), have developed ways of using the media that are completely different from those used by their parents. They do not distinguish between "the world" and "the world of the media". They are children in the world of the Internet and the Internet is part of their "real-virtual" world. However, research that has shown that adolescents are active and self-confident media users, also warns of their marked naivety (hrkids.online, 2018; Buckingham, 2000). The Internet today strongly influences its users and their thinking, but also has influence on their own personality. The problems mentioned by different scholars and researchers related to the use of media, especially of the Internet by children and youth, are: exposure of children to violence and inappropriate content because of the impossibility of legal regulation of all Internet sites, but also the alienation of children, cyberbullying, violence, sexualisation and addiction (hrkids.online, 2018; Young and Nabuco de Abreu, 2011). Keeping in mind that children and youths are increasingly surrounded by the media, we cannot ignore their influence on the behaviour and performance of these children and youths. Furthermore, on the basis of the aforementioned studies by various researchers, we have to think of digital media literacy as a valid, useful and necessary educational key for the future of education in schools and in families, not just for children and youths, but for teachers and parents, too. 


\section{DIGITAL MEDIA LITERACY AS EDUCATION KEY}

The thesis that digital media literacy is a valid educational key for the future of education in schools and in families, as mentioned before, is confirmed by Sonia Livingstone and Julian Sefton-Green. They write that "some of the ways in which digitally networked, convergent technologies have entered people's ordinary lives may facilitate socially progressive change - supporting youth participation and creative and learning opportunities and providing resources designed for disadvantaged groups. At the same time, there is reason to fear that those same technologies are, with perhaps grater force, being actively reinvented by powerful elites to ensure that political and commercial logics dominate. However, in drawing attention to technologies in this way, we emphasize that they gain their meaning through particular practices and contexts of design and use" (Livingstone and Sefton-Green, 2016: 5). Continuing this reflexion, they add that "it is not just digital technologies that make for change between the present and previous generations - many other changes have shaped the possibilities for and influences on young people in recent decades, and these changes have been more thoroughly researched and theorized", which will be demonstrated by some of the results of the studies we are going to present and to analyse later in this article, aiming to reveal the habits of using the media by children, young people and their parents. In the aforementioned paper, Livingstone and Sefton-Green aim to answer "abstract historical and sociological questions with the everyday experiences of our class", investigating some points of living in Late Modernity (Livingstone and Sefton-Green, 2016: 23-26), "in which the contrary forces of socio-technological innovation and the reproduction of traditional structures (the school, the family, social class) threaten to pull young people in different directions" (Livingstone and Sefton-Green, 2016: 11). In their research, conducted over the course of one year with 28 teenagers at home, at school, with their friends and online, they discovered that the media "- both mass and networked - were heavily implicated in the domestic settings of values, emotions, and identities" (Livingstone and SeftonGreen, 2016: 15), "that crucial changes to home and family have affected children's and young people's lives over recent decades", and that these "large-scale social changes have implications for the private life of families" (Livingstone and Sefton-Green, 2016: 27), of school and of education (Livingstone and Sefton-Green, 2016: 30-32). For children, the media offer "rich resources to explore and express their growing independence, as well as to engage in pleasures that were not always favoured by their parents" (Livingstone and Sefton-Green, 2016: 156), who were concerned about Internet use.

While Turkle writes about living "alone together", Livingstone and Sefton-Green state that "in the $21^{\text {st }}$ century, coming together 'as a family' is ever more a matter of choice than of necessity", pointing out that families today are "living together and separately" (Livingstone and Sefton-Green, 2016: 164f), concluding that there is a need "to reconcile young people's everyday experiences with the many hopes and fears about youth in the digital age" (Livingstone and Sefton-Green, 2016: 233), the need to manage "the balance between time together and time apart" because "most of the families put a lot of effort into finding ways to come together" (Livingstone and Sefton-Green, 2016: 244-245). In this contemporary context, critical digital media literacy is needed and "founded on 
the legitimate role of media to serve the public's right to be truly informed" (Torres and Mercado, 2006: 260), and to be educated and literate. In fact, in today's digital age, there is no need and no space to talk about a "generational divide" or gap between "digital natives" (children) and "digital immigrants" (parents) because times have changed and we all need to became "digitally wise" and to be dedicated to media digital literacy in our everyday lives. Indeed, in our time, we are talking about digital parenting. And "digital parenting is a popular yet polysemic concept that refers both to how parents are increasingly engaged in regulating their children's relationships with digital media (parental mediation), and how parents themselves incorporate digital media in their daily activities and parenting practices, and, in so doing, develop emergent forms of parenting" (Mascheroni et al., 2018: 9).

The study on parental mediation of children's Internet use carried out by Sonia Livingstone et al. came to the conclusion that the diverse array of mediation practices employed by parents can actually be grouped into two broad categories: enabling and restrictive mediation. "While restrictive mediation can be effective in reducing children's exposure to online risks, it has numerous side-effects, because it limits children's opportunities to develop digital literacy and build resilience and discourages children's agency within the child-parent relationship. Enabling mediation, instead, encompasses a set of mediation practices (including co-use, active mediation of Internet safety, monitoring and technical restrictions such as parental controls) that are aimed at empowering children and supporting their active engagement with online media" (Livingstone et al., 2017, according to Mascheroni et al., 2018: 9-10). According to Mascheroni, et al., the question is how "to ensure children's access to online opportunities while protecting them from potential harmful effects. This question is particularly pressing for younger children, who are now increasingly online even before they can talk or walk. However, there is still a paucity of research on parental mediation of very young children regarding their digital media uses. Available research suggests that parents of younger children tend to favour restrictive mediation, though they are inconsistent in their practices and often use touchscreens as a babysitter while they are doing household chores, or as part of a system of reward and punishment for children's behaviour (Chaudron et al., 2015). The appropriation of digital media into families' everyday lives is influenced by parenting styles or ethics" (Clark, 2013, according to Mascheroni et al., 2018: 10), by their various "equipment" to face the increasing complexity of the digital world and its social and developmental consequences, by inequalities in parental mediation because of parents' different level of education or socio-economic status. "Even among parents of young children, lower income/lower educated parents are likely to experience a generational digital divide and feel less confident in their ability to guide children's use of touchscreens and prevent their exposure to risks. As a consequence, they are reluctant to engage in parental mediation and scaffolding of their children's digital literacy practices. Children are left to experiment on their own, learning by trial and error, or seek out support from their older siblings"(Mascheroni et al., 2016, according to Mascheroni et al., 2018: 10). Today's children act as agents of change in families; they are introducing new technologies, "reversing existing media rules or creating new rules, guiding their parents' use, and mediating media effects (van den Bulck et al., 2016). The so-called 'child-effect' (van den 
Bulck et al., 2016) invites the researcher to consider mediation as a reciprocal process, whereby both parents and children and the family as a cultural unit are transformed. Families with children are usually early and enthusiastic adopters of new technologies, which, in turn, shape the family's communication practices and media consumption habits. However, and despite the fact that the child-effect can and, to varying degrees, does occur in all families, it has been largely under-investigated so far" (ibid., 2018).

How are parents in Croatia facing these new educational challenges? Are they controlling their children or are they more open to monitor, to discuss with their children about the new educational possibilities provided by digital media? These are some of the aims of the different studies that we present and analyse.

\section{THE EDUCATIONAL SYSTEM IN CROATIA AND COMPUTER AND MEDIA LITERACY}

As for media education in Croatia, there is no separate school subject devoted solely to the media, but media literacy is a part of the Croatian Language subject in elementary school, from the first to the eighth grade. Therefore, the emphasis is on film and theatre, while the new media are almost completely omitted. Suffice it to say that in eight years, as far as primary school in Croatia is concerned, there is only one teaching unit dedicated to the Internet, in the sixth grade. In this unit, the network is defined and students have to find several web pages on the topics of the Croatian Language and Literature (Vican and Milanović Litre, 2006: 41). The unit does not stimulate critical thinking nor does it address the actuality of the new media, especially in children and young people's life. However, the amount of competences children will actually acquire through compulsory media education depends first and foremost on each teacher individually and his/her decision on how many hours per year will be devoted to media education (many teachers spend less than mandatory nine to ten hours a year) (Ciboci, 2018; Ciboci and Osmančević, 2015).

Apart from the Croatian Language classes, students also acquire key media and digital competences "within Technical Education and Informatics subjects as well as within intercurricular themes" (Kanižaj and Car, 2015: 27). Until this school year, Informatics at elementary school was an extracurricular activity from the first to the fourth grade and an elective course from the fifth to the eighth grade (Vican and Milanović Litre, 2006: 310) which means that not all students had the opportunity to acquire all the necessary digital knowledge. However, pedagogues and psychologists played an important role in all these years of obligatory schooling by holding lectures about Internet security and cyberbullying to children in schools.

Much has changed in the current school year because the experimental curricular reform is underway in Croatia. Along with others, one of the main changes refers to Informatics which has become a compulsory subject in the fifth and sixth grades. Today, within the curriculum of Informatics, students learn about topics such as network security, data protection, electronic violence and concern for their digital reputation, personal data 
protection, inappropriate forms of behaviour and seeking help for unwanted content or contacts (Nacionalni kurikulum nastavnoga predmeta - Informatika - prijedlog, 2016: 5). The proposal of the Curriculum of Informatics is much more up-to-date than the previous one, and it meets the needs of today's average media user. The Curriculum of Informatics significantly complements the curriculum of Croatian Language and offers the competencies needed in today's information age.

The existing curriculum is not to be discarded, but today's students need additional media knowledge to be able to enjoy all the benefits they provide. This knowledge implies taking into account all the dangers they might encounter, with particular emphasis on those related to the Internet, the medium on which children spend most of their free time. Therefore, the parents should have a key role in this process.

\section{PARENTS AS DIGITAL EDUCATORS OF CHILDREN IN CROATIA}

In November 2017, the first national representative survey on children's digital habits was conducted in Croatia. The study involved 1,017 children aged nine to seventeen and their parents. The youth sample was stratified in terms of the size of counties, as well as age and gender of the children, and the survey was administered using the CAPI method. The Association for Communication and Media Culture ${ }^{1}$ conducted the research in cooperation with the Agency for electronic media, the City of Zagreb, Croatian Telecom, the Croatian Regulatory Authority for Network Industries and the Centre for Missing and Abused Children. The research was supported by the Ministry of Science and Education and the Ministry of Demography, Family, Youth and Social Policy. The research was carried out by Ipsos Puls. The aim of the research was to analyse the habits of children in Internet usage, the exposure to risky contents, but also to analyse the role of parents in using and protecting children on the Internet. The survey was conceptualized and conducted as part of an international research project, the follow-up project of the original EU Kids Online survey conducted in 2010 in $25 \mathrm{EU}$ member states. This paper presents the findings of the EU Kids Online 2017 survey conducted in Croatia in September and October 2017. The preliminary results of the research were published on the official website of the project - http://hrkids.online/. This paper provides unpublished results on parental attitudes about children's Internet usage and their role in ensuring the protection of children on the Internet as well as their satisfaction with media literacy education within the Croatian school system.

The study involved 1,017 parents - 797 mothers and 220 fathers. The questionnaire was answered by the parent in the household who claimed that he or she was better acquainted with the digital habits of the child. As far as the educational structure of the respondents is concerned, $71.8 \%$ of them have high school education qualifications, $20.9 \%$ have higher education qualifications or higher, while $7.3 \%$ of respondents have elementary school qualifications or uncompleted elementary school. Most of the respondents, $82 \%$ of them, live in households with an average monthly income, $12.5 \%$ in households below

\footnotetext{
${ }^{1}$ The authors of this paper are members of the Association.
} 
the average monthly income, while $5.5 \%$ of respondents live in households above the average income.

\section{Results with Discussion}

The Internet is present in everyday lives of parents, not only of children. Specifically, $84.5 \%$ of parents use the Internet every day, $8.5 \%$ at least once a week, $2.4 \%$ at least once a month, $0.4 \%$ at least once a year, and only $4.3 \%$ of parents do not use the Internet. Parents, as well as children (http://hrkids.online/, 2017), most often access the Internet via smartphones, much more often than via computers, laptops or tablets (Figure 1).

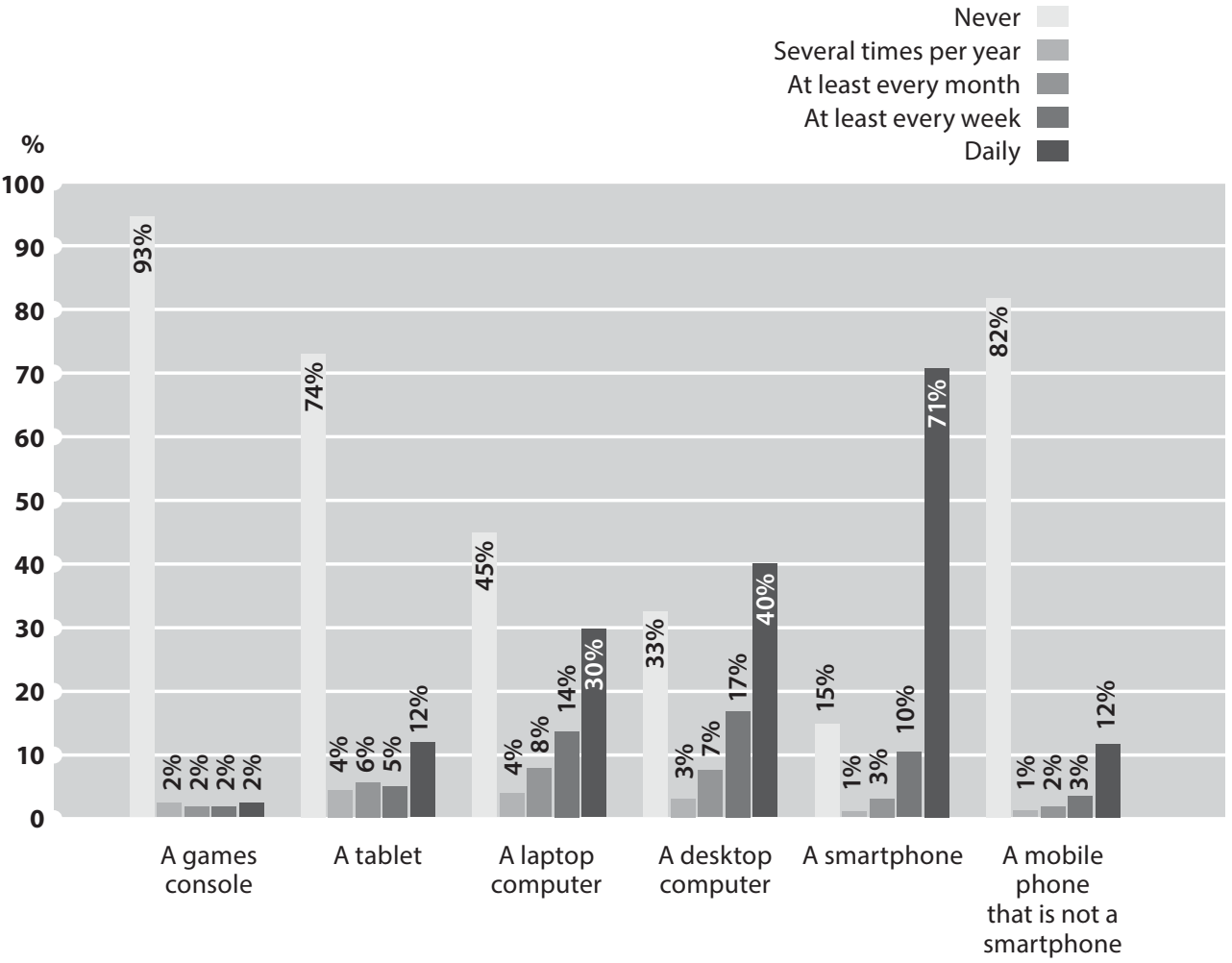

A Figure 1.

The usage of devices to access the Internet $(\mathrm{N}=1017)$

Research showed that $69.4 \%$ of parents believe that their child uses the Internet better than they do. The survey found that $71.3 \%$ of mothers and $62.7 \%$ of fathers think in this manner. Such data should not be surprising given the fact that every fourth parent 
was over 30 years old when they first started using the Internet. The results showed that $2.1 \%$ of parents started to use the Internet for the first time by the age of $10,29.8 \%$ of parents between 11 and 20 years, $35.8 \%$ between 21 and 30 years, 21\% between 31 and 40 years, $4.3 \%$ between 41 and 50 and $0.6 \%$ when they were over 50 years old. There was no difference in the respondents' perception based on monthly income. However, there was a statistically significant difference considering the education of the respondents - those with elementary and secondary education significantly more often believe that children use the Internet better than they do.

Since most parents believe children use the Internet better than they do, it is important to help them, especially by providing information and advice on how to keep their children safe on the Internet. Research has shown that most often parents receive such information from the media, family and friends, as well as from their child's school (Figure 2). However, in the future, as it can be seen in Figure 2, parents would like to receive such information primarily from their child's school and far less from the media themselves. Parents have clearly pointed out that the role of school is not only the education of children, but the education of adults as well. School needs to provide the support to adults in child education, especially in those areas where children spend a lot of their time and potentially have more knowledge than their own parents. Digital education surely is one of them. These results show that parents, when it comes to the safety of children on the Internet, have more confidence in school itself than in the media. Although it cannot be said with certainty, it can be assumed that if parents gain more knowledge of the Internet, particularly of its educative role, it is likely that they will more often encourage the usage of the Internet for educational purposes at home, but further research in this area is certainly needed. Apart from additional research on the role of school in the digital education of parents, it is necessary to explore how to encourage them to participate in school education. Specifically, previous research shows that such education in Croatian schools is most often responded by the same parents, enthusiasts, who often do not need such education, while the parents who need such education most often do not participate in these programmes (Ciboci, 2018).

The graph provided in Figure 2. also shows that many parents (38.2\%) receive information about child safety on the Internet from children themselves, which places doubt on their ability to monitor their children, as well as to help their own children in case of exposure to inappropriate content. It is interesting to note that a high $41.7 \%$ of parents would like to continue in the future with such practice, showing that parents see nothing wrong in the fact that children are educating them on the use of new media. Although in online contexts "everyone learns from everyone" with the flattening of traditional hierarchies between teachers and learners, parents have much more life experience than children, which enables them to look more critically on media content. The child may be able to teach parents how to open, for instance, a profile on a social network, but is a child aware of both positive and negative aspects of social networks? For example, are they aware of suspect credibility and reliability of information published there? Although children can teach their parents technical knowledge of media and new technologies, parents need to develop critical evaluation of this same media content in children. 


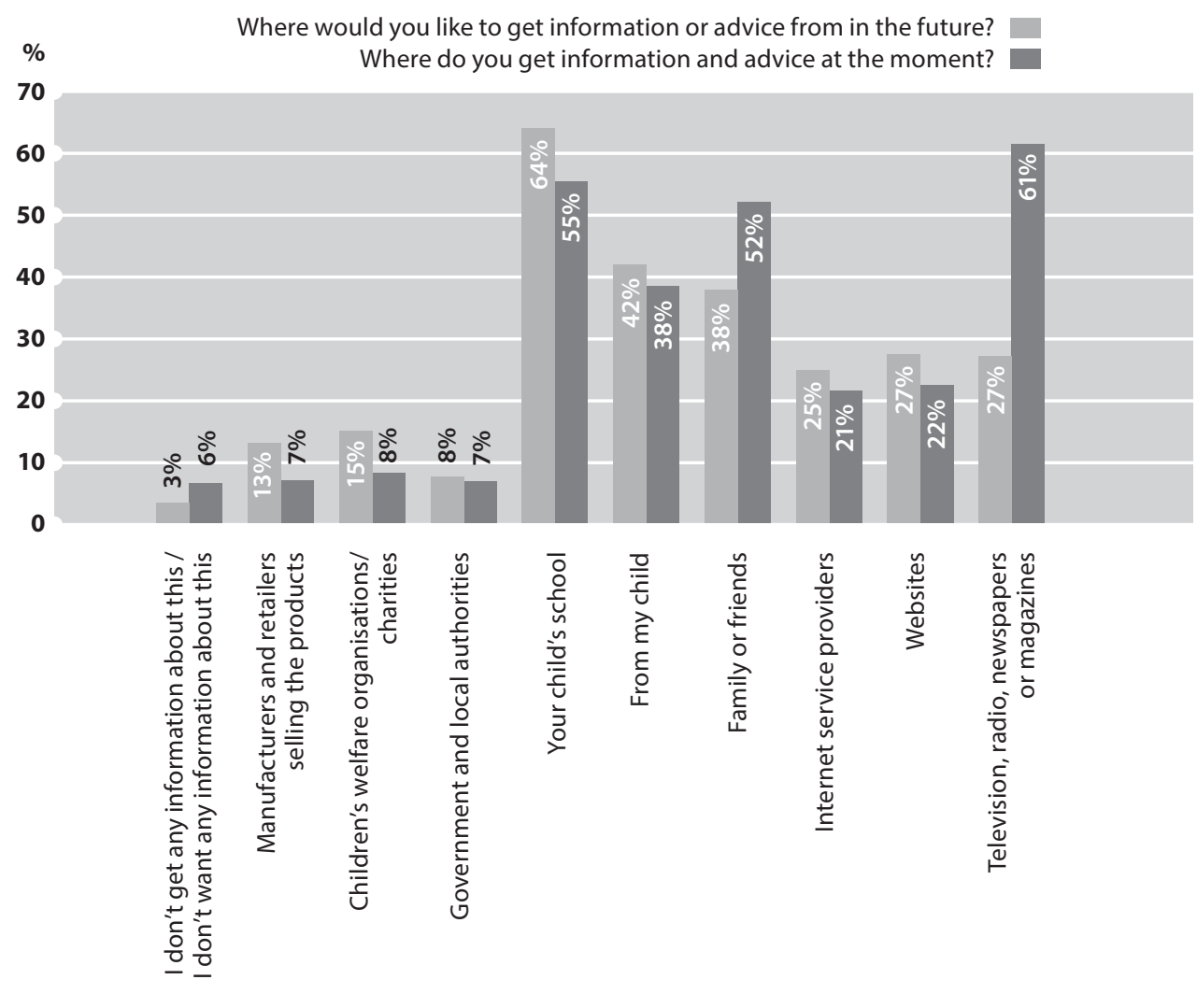

A Figure 2.

Getting information and advice on how to help and support children on the Internet

$(\mathrm{N}=1$ 017)

\section{Active or Restrictive Parental Mediation Strategies}

The research showed that greater parental engagement in their children's online behaviour is necessary. In point of fact, children have much bigger experience in online contacts with someone they have not met face to face in comparison to their parents' views and attitudes (Ciboci, et al., 2019).

The study showed that parents rarely use restrictive parental mediation strategies. As a matter of fact, $60.1 \%$ of parents always allow children to visit social networks, even to children under the age of $13 ; 44.8 \%$ of parents always allow their children to post photos, videos or music online to share with others; $47.5 \%$ of parents always allow their children to play games with other people online, while $54.9 \%$ of parents always allow their children to download music or films. 


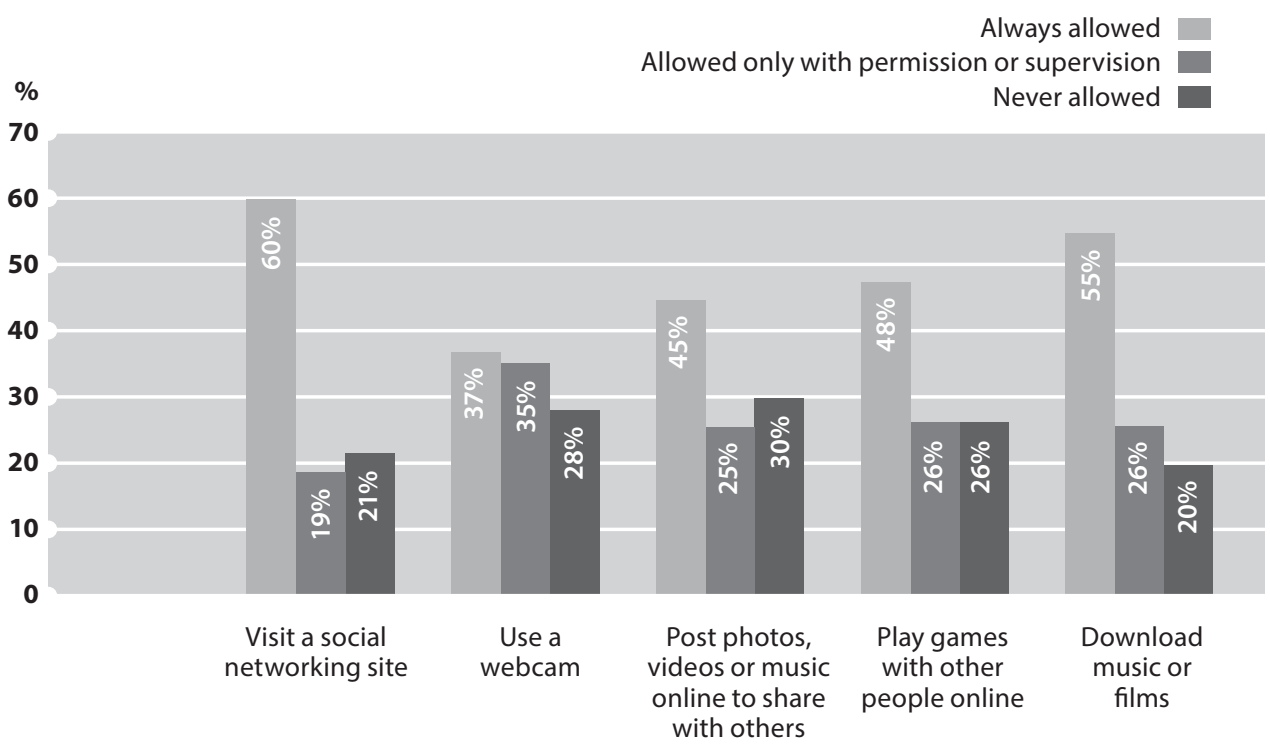

$\Delta$ Figure 3.
Parental restrictive mediation strategies
$(\mathrm{N}=1017)$

When their child uses the Internet, $76.4 \%$ of parents talk with their child about what he/she does on the Internet. ${ }^{2}$ However, when talking about other parental mediation strategies, parents rarely use them to educate their children. Only $13.4 \%$ of parents sit with their child while he/she uses the Internet, $31.4 \%$ of parents stay nearby when their child uses the Internet, and $32.7 \%$ of parents do shared activities together with their child on the Internet. Parents are rarely involved in raising and educating their children about the Internet, which further indicates the importance of educational institutions.

The above results show that some parents use strategies that are rooted in monitoring practices or co-using strategies and that most parents talk with children about the Internet. What we do not know is what kind of talk is used. Therefore, in the future research it is highly recommended to analyze the content parents are discussing with children.

${ }^{2}$ A multiple choice question, parents were free to check all the boxes if they were engaged in all four practices. 


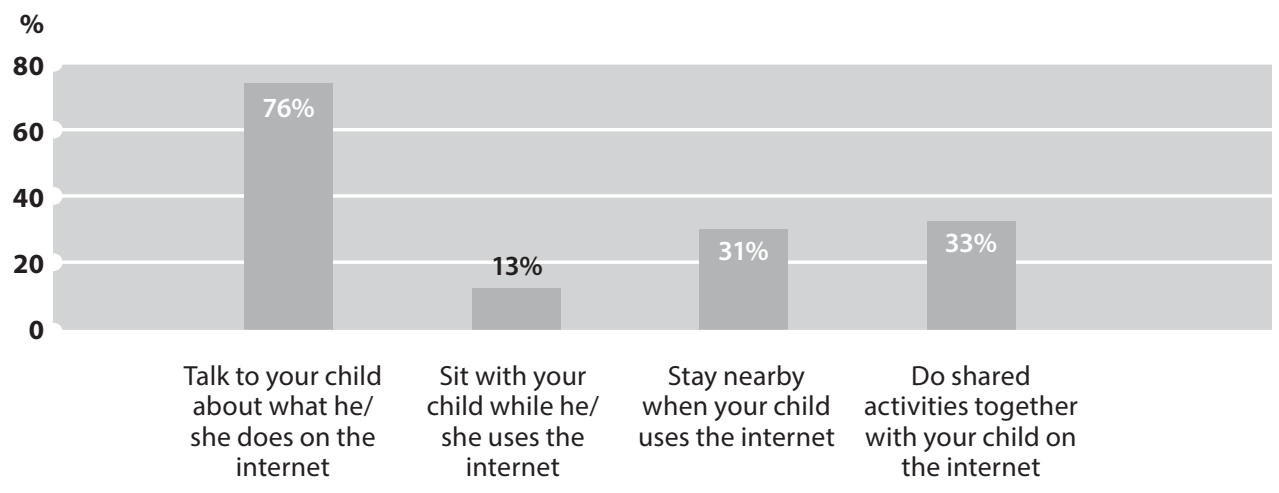

$\Delta$ Figure 4.

Parental active mediation strategies

$(\mathrm{N}=1.017)$

\section{Parental Satisfaction with Media and Digital Literacy Teaching in Croatia}

School plays a significant role in children's media education. On the one hand, parents see it as an important actor to transfer knowledge and provide information to parents on how to protect children on the Internet, but, on the other hand, they think that teachers are, together with parents, responsible for children's media education. Our research showed that $80.2 \%$ of parents think that media education should be their responsibility, and $74.8 \%$ hold the view that educators in pre-school and school should be responsible for educating their children on the media ${ }^{3}$.

Although they emphasize the importance of educators and teachers in media education of children, parents still do not recognize the importance of media education of children from the earliest age. Although children spend hours and hours using the Internet even before they go to school and many children start to use the Internet already in their first years of life (Chaudron, 2015), most parents think that media education should start in elementary school, from the first to the fourth grade. Every fifth parent thinks that media education should begin from the fifth to the eighth grade (Figure 5). Only every fifth parent thinks that media education should start from the earliest age, already in kindergarten. 


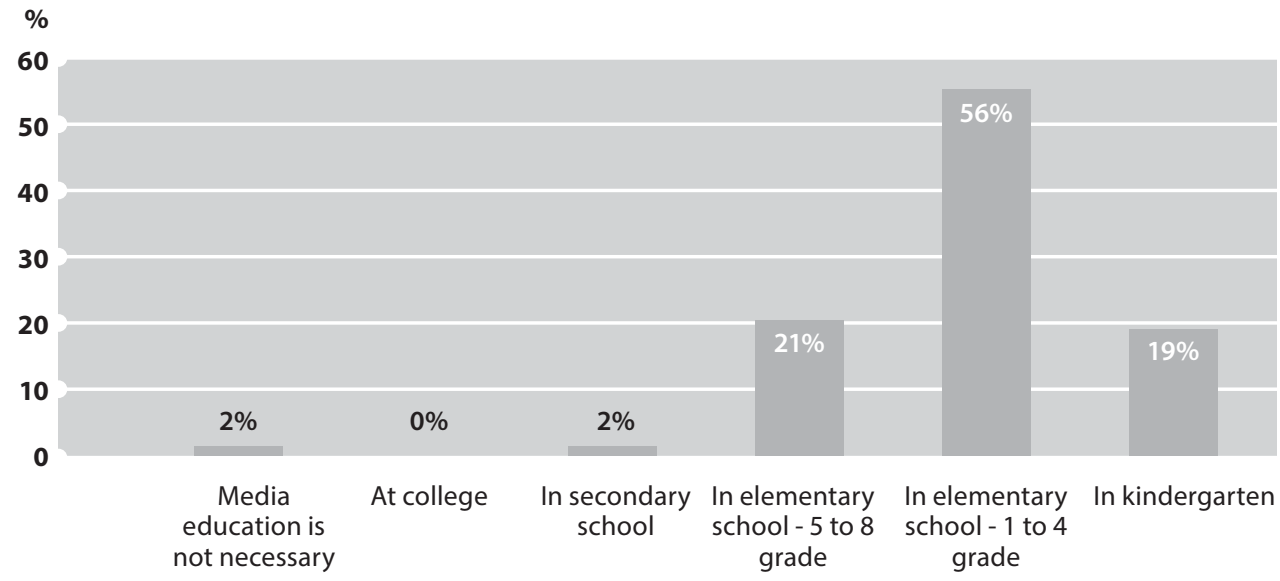

A Figure 5 .

Parental opinion on when media education should begin

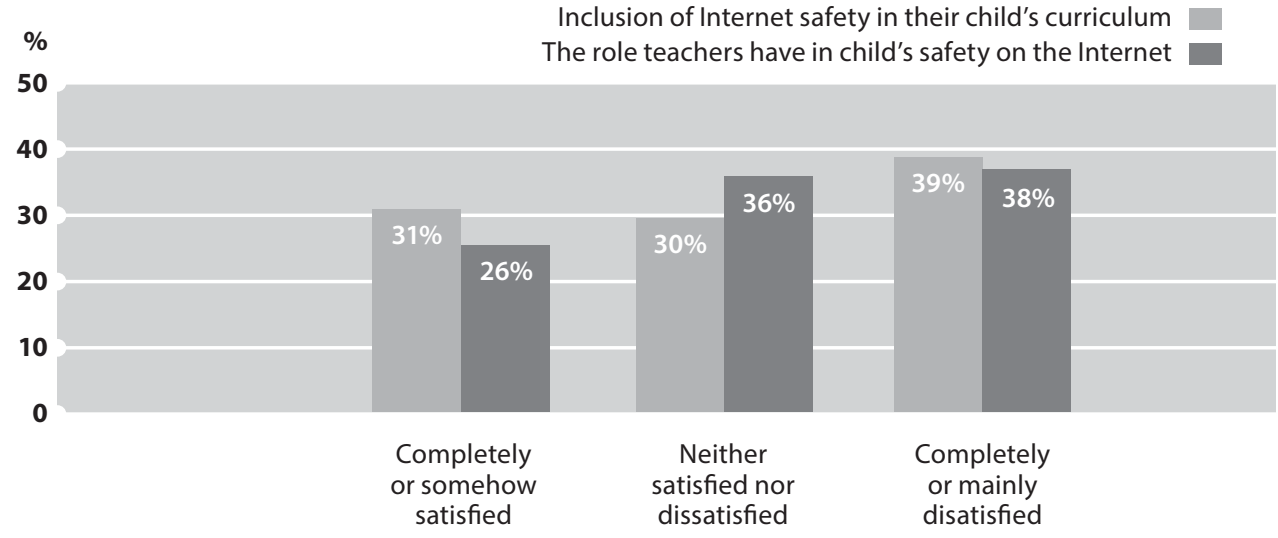

$\Delta$ Figure 6.

Parental satisfaction with digital literacy in schools

$(\mathrm{N}=1$ 017) 
Although parents think that teachers play an important role in their children's digital and media education, results show that parents are more dissatisfied than they are satisfied with the inclusion of Internet safety in their child's curriculum as well as with the role teachers have in child safety on the Internet. This shows that parents themselves think that changes, especially in terms of children's online safety, are more than necessary.

\section{CONCLUSION}

Today's parents more than ever need help in raising their children. While children are growing up with the media, many parents started to use them at an older age, so it does not come as a surprise that many parents think that children use the Internet better than they do. It can be expected that this knowledge gap in Internet usage will begin to decline when these generations of children who grew up with the Internet from the earliest age start to have their own children. Nevertheless, before this happens, parents need help and educational institutions play a particularly important role. In their research, researchers are increasingly warning about not only the positive, but also the negative effects of the media and media content that may harm the development of children and youth. In addition, parents themselves have to learn how to educate their children in the new digital media environment. However, they lack the knowledge and skills associated with digital literacy and are particularly concerned about the safety of children in the online world. Parents are dissatisfied with inclusion of online safety in the Croatian educational system. They are also dissatisfied with the role of teachers in protecting children on the Internet. On the other hand, as far as media and digital education are concerned, school is seen by parents as a key actor in providing them with information and advice on how to protect children online. Therefore, schools are equally important in the education of parents, not only children. It is important to alert school principals and teachers to the need for the digital education of parents and to continue organizing lectures and workshops on this subject.

Apart from school, parents have often received such information from the media themselves. It shows just how important it is for the media themselves to offer quality content and that their role is to educate media users. Even though the current law in Croatia is applied only to public broadcast media, due to the influence that media have on the lives of media consumers, it is important that the "burden" of media education is equally assumed by all the media. Based on the new Audiovisual Media Services Directive (AVMSD) of 2018, this became obligatory for all the media.

Parents need help in educating children in this digital age. This help is needed by all stakeholders - schools, media, family members, but also children themselves. It is, therefore, important to work on the digital literacy of all media users in order to protect children online and to ensure a peaceful and quality childhood with the media. 
This research has shown the need for further research. In the future, it is recommended to conduct a comparative analysis of other countries and see how they conduct media and digital literacy of adults, especially of parents, and investigate whether this role was taken over by the media or school itself. It would be useful to see how they encouraged parents to attend training in school, especially in areas where they lack knowledge. It should also be worth exploring the ways in which educators in these countries were educated to work with parents. Furthermore, it would be worth exploring the opinions of schools, principals and teachers on this topic. There is a need to conduct qualitative research that will provide deeper insight into how parents educate children about the media, to which topics they devote most of their attention and what kind of advice they provide to them. This is an area that is certainly of great significance and needs to be further explored in future research.

\section{References}

>Blades, Mark; Oates, Caroline; Blumberg, Fran and Gunter, Barrie (2014) (eds) Advertising to Children. New Directions, New Media. London: Palgrave Macmillan. DOI: 10.1057/9781137313256. >Buckingham, David (2000) After the Death of Childhood, Growing up in the Age of Electronic Media. Cambridge: Polity Press.

>Carlisle, Kristy L.; Carlisle, Robert M.; Polychronopoulos, Gina B.; Goodman-Scott, Emily, and KirkJenkins, Andrea (2016) Exploring Internet Addiction as a Process Addiction, Journal of Mental Health Counseling 38 (2): 170-182. DOI:10.17744/mehc.38.2.07.

>Ciboci, Lana (2018) Vrednovanje programa medijske kulture u medijskom opismenjivanju učenika osnovnih škola. (Doktorska disertacija). Zagreb: Filozofski fakultet, Sveučilište u Zagrebu.

>Ciboci, Lana; Kanižaj, Igor and Potočnik, Dunja (2019) Unchanged agenda around digital risks: predominant restrictive mediation in Croatia (unpublished manuscript).

>Ciboci, Lana, and Osmančević, Leali (2015) Kompetentnost nastavnika hrvatskoga jezika za provođenje medijske kulture u hrvatskim osnovnim školama, pp. 121-138 in Car, Viktorija; Turčilo, Lejla and Matović, Marijana (eds) Medijska pismenost - preduvjet za odgovorne medije. Sarajevo: Fakultet političkih nauka Univerziteta u Sarajevu.

$>$ Chaudron, Stéphane (2015) Young Children (0-8) and Digital Technology - A qualitative exploratory study across seven countries. Luxembourg: Publications Office of the European Union. >Elea, Ilana and Miklos, Lothar (2017) (eds) Young and Creative - Digital Technologies Empowering Children in Everyday Life. Göteborg: Nordicom - University of Gothenburg. >Erjavec, Karmen (2005) Odgoj za medije: od koncepta do školske prakse, pp. 77-106 in Zgrabljić Rotar, Nada (ed.) Medijska pismenost i civilno društvo. Sarajevo: Mediacentar.

>Frau-Meigs, Divina (2015) Augmented Media and Information Literacy (MIL). How Can MIL Harness the Affordances of Digital Information Cultures?, pp. 13-25 in: Kotilainen, Sirkku and Kupiainen, Reijo (eds) Reflections on Media Education Futures. Göteborg: Nordicom - University of Gothenburg. >Kanižaj, Igor and Car, Viktorija (2015) Hrvatska: Nove prilike za sustavan pristup medijskoj pismenosti, pp. 23-41 in Car, Viktorija; Turčilo, Lejla and Matović, Marijana (eds) Medijska pismenost preduvjet za odgovorne medije. Sarajevo: Fakultet političkih nauka.

>Kirsh, Steven J.M. (2006) Children, Adolescents, and Media Violence: A Critical Look at the Research. Thousand Oaks: Sage Publications. DOI: 10.4135/9781452204253. >Lemish, Dafna and Götz, Maya (2017) (eds) Beyond the Stereotypes? Images of Boys and Girls and their Consequences. Göteborg: Nordicom - University of Gothenburg.

>Li, Wen; O'Brien, Jennifer E.; Snyder, Susan M. and Howard, Matthew O. (2015) Characteristics of Internet Addiction/ Pathological Internet Use in U.S. University Students: A Qualitative-Method Investigation. PLoS One, 10 (2): e0117372. DOI: 10.1371/journal.pone.0117372. 
$>$ Lin, Fuchun and Lei, Hao (2015) Structural Brain Imaging and Internet Addiction, pp. 21-42. in Montag, Christian and Reuter, Martin (eds) Internet Addiction: Neuroscientific Approaches and Therapeutical Interventions. Cham: Springer International Publishing. DOI: 10.1007/978-3-319-07242$5 \_2$.

>Livingstone, Sonia and Sefton-Green, Julian (2016) The Class Living and the Learning in the Digital Age. New York: New York University Press. DOI: 10.18574/nyu/9781479884575.001.0001. $>$ Mascheroni, Giovanna and Pasquali, Francesca (2013) Dress Up and What Else? Girls' Online Gaming, Media Culture and Consumer Culture. CM - Časopis za upravljanje komuniciranjem 8 (29): 79-102. DOI: 10.5937/comman1329079m.

>Mascheroni, Giovanna; Ponte, Cristina and Jorge, Ana (2018) (eds) Digital Parenting - The Challenges for Families in the Digital Age. Göteborg: Nordicom - University of Gothenburg. >Ministarstvo znanosti i obrazovanja (2016) Nacionalni kurikulum nastavnoga predmeta: informatika - prijedlog. http://www.kurikulum.hr/wp-content/uploads/2016/03/Informatika.pdf (10.04.2017.). $>$ Perdew, Laura (2014) Internet addiction. North Mankato (Minnesota): Abdo Publishing. $>$ Pereira, Sara (2013) More technology, better childhoods? The case of the Portuguese 'one laptop per child' programme. CM - Časopis za upravljanje komuniciranjem 8 (29): 171-197. DOI: 10.5937/ comman1329171p.

>Spitzer, Manfred (2018) Digitalna demencija. Kako mi i naša djeca silazimo s uma, Zagreb: Ljevak >Sundin, Ebba (2013) The Complex Process of Children's Identity in New Landscapes of Media and Culture. CM - Časopis za upravljanje komuniciranjem 8 (29): 17-36. DOI: 10.5937/comman1329017s. >Tilleul, Camille; Fastrez, Pierre and De Smedt, Thierry (2015) Evaluating Media Literacy and Media Education Competences of Future Media Educators, pp. 75-89 in Kotilainen, Sirkku and Kupiainen, Reijo (eds) Reflections on Media Education Futures. Göteborg: Nordicom - University of Gothenburg. $>$ Torres, Myriam Nohemi and Mercado, Maria (2006) The Need for Critical Media Literacy in Teacher Education Core Curricula, Educational Studies 39 (3): 260-282.

$>$ Turkle, Sherry (2011) Alone Together: Why We Expect More from Technology and Less from Each Other. New York: Basic Books.

$>$ Young, Kimberly S. (2018) Screen Addiction. http://netaddiction.com/compulsive-surfing/ $(20 / 3 / 2019)$.

$>$ Young, Kimberly S. and Nabuco de Abreu, Cristiano (2011) Internet addiction, A Handbook and Guide to Evaluation and Treatment. New Jersey: John Wiley \& Sons, Inc. DOI: 10.1002/9781118013991. $>$ Vican, Dijana and Milanović Litre, Ivan (2006) Nastavni plan i program za osnovnu školu. Zagreb: Ministarstvo znanosti, obrazovanja i sporta.

$>$ Weinstein, Aviv; Curtiss Feder, Laura; Rosenberg, Kenneth Paul and Dannon, Pinhas (2014) Internet Addiction Disorder: Overview and Controversies, pp. 99-117 in Rosenberg, Kenneth Paul and Curtiss Feder, Laura (eds) Behavioral Addictions: Criteria, Evidence, and Treatment. Cambridge, Massachusetts: Academic Pres. DOI: 10.1016/b978-0-12-407724-9.00005-7.

>Zgrabljić Rotar, Nada (2005) Mediji - medijska pismenost, medijski sadržaji i medijski utjecaji, pp. 9-43 in Zgrabljić Rotar, Nada (ed.) Medijska pismenost i civilno društvo. Sarajevo: Mediacentar. 


\section{MEDIJSKA I DIGITALNA PISMENOST: ŠKOLA I SUVREMENO RODITELJSTVO}

\section{Lana Ciboci :: Danijel Labaš}

SAŽETAK Živimo u svijetu u kojem mediji konstruiraju stvarnost, ali i utječu na svakoga korisnika medija. Novim digitalnim medijima i njihovim sadržajima posebno su izložena djeca, pa znanstvenici u svojim istraživanjima veliku pozornost pridaju medijskoj i digitalnoj pismenosti. Pri tome vode računa o novim pojavama, izazovima i rizicima koji su povezani s antropološkim, kognitivnim i socijalnim razvojem djece i mladih. Posebnu pozornost posvećuju socijabilnosti djece i mladih, ali i korisnika medija općenito, rizicima razvijanja raznih oblika ovisnosti o internetu i digitalne demencije. Važnu ulogu u medijskom odgoju imaju ne samo učitelji i škole nego i roditelji i obitelj. Cilj je ovoga rada prikazati i analizirati teorijske pristupe medijskoj i digitalnoj pismenosti i takozvanom digitalnom roditeljstvu te izložiti i protumačiti rezultate najnovijih istraživanja u Hrvatskoj o digitalnim navikama djece, odnosno njihovih roditelja, te o ulozi i mjestu roditelja u procesu medijskoga opismenjavanja djece i mladih, kao i o njihovu zadovoljstvu programima medijske pismenosti u odgojno-obrazovnom sustavu.

\section{KLJUČNE RIJEČI}

MEDIJSKA PISMENOST, DIGITALNA PISMENOST, DJECA, RODITELJI, STRATEGIJE POSREDOVANJA

Bilješka o autorima

Lana Ciboci :: Edward Bernays Visoka škola za komunikacijski menadžment, Zagreb, Hrvatska :: Iciboci@gmail.com

Danijel Labaš :: Sveučilište u Zagrebu, Hrvatski studiji, Zagreb, Hrvatska :: dlabas@hrstud.hr 